\title{
O NARRADOR URBANO DIGITAL EM FOCO: O CASO DE MARCO ALMEIDA, O MARAGATO
}

\author{
Mauren Pavão Przybylski*
}

\begin{abstract}
RESUMO: O presente artigo pretende, a partir dos estudos literários e de "media", comprovar a existência de um narrador oral urbano-digital. Nossa reflexão estará organizada em 4 momentos: 1) Situando o campo: a Restinga, em que traremos, além da apresentação deste bairro periférico $e$ seus narradores, nossas motivações para com a pesquisa; 2) A relação academia, periferia e narrativa: a remediação e o digital, em que enfocaremos elementos dos estudos digitais e o conceito de remediação para apresentar a narrativa oral urbano-digital e nossa relação de pesquisadores para com os moradores deste bairro periférico; 3) Do conceito de narrativa digital hiperficcional, sobre o qual intentaremos discorrer para, assim, definirmos o narrador urbanodigital, a partir da narrativa interativo-ficcional do "Maragato" e; 4) Para concluir, em que pontuaremos algumas das conclusões a que se chegou com a pesquisa.
\end{abstract}

PALAVRAS-CHAVE: Estudos de media. Narrador oral urbano-digital. Narrativa. Periferia.

\section{Situando o campo: a Restinga e seus narradores.}

Narrar o outro não é tarefa de fácil realização. É preciso entender que cada um narra aquilo que espera ser uma valorização do seu eu e de sua história e que sempre há uma experiência prévia a qual o levou a narrar. Se este texto, para que não se torne ainda mais extenso, não adentrará nas teorias da narrativa propriamente ditas, faz-se necessário deixar claro que faremos, o tempo todo, esse movimento de ir e vir; ir para o campo e voltar para a escrita, com o objetivo de sermos mediadores de várias histórias e subjetividades, pertencentes ao que Manuel Castells (2005) chamou de sociedade em rede ${ }^{1}$, no capítulo inicial da obra A sociedade em rede em Portugal.

Universidade Federal do Rio Grande do Sul, Porto Alegre, Brasil. Imeio: maurenpavao@gmail.com.

${ }^{1}$ Diz Castells (2005, p. 19): Assim, a sociedade em rede é a estrutura social dominante do planeta, a que vai absorvendo pouco a pouco as outras formas de ser e existir. Isso, em si mesmo, não é bom nem mau: é. E as suas consequências, como no caso de outras sociedades que existiram historicamente, dependem do que as pessoas fazem, incluindo nós, nessa sociedade e com os instrumentos que essa sociedade oferece.

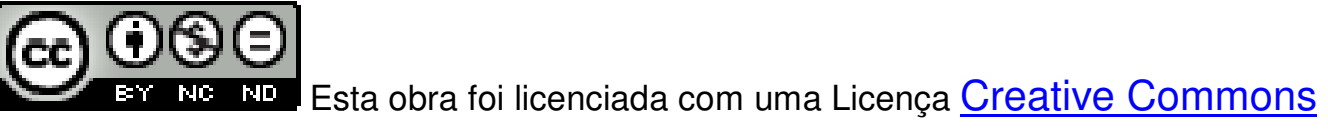

Texto Digital, Florianópolis, v. 10, n. 1, p. 76-101, jan./jul. 2014. ISSNe: 1807-9288 
A pesquisa aqui apresentada entende que a literatura não precisa ser só escrita: ela é também oral. Faz parte dela a escuta, a fala, a escrita e a leitura, porque todos esses pilares serão formadores das histórias que os sujeitos irão narrar.

Por isso, narrar a Restinga ${ }^{2}$ não foi uma ideia que surgiu ao acaso; ao contrário, veio da experiência propiciada pela pesquisa de campo. Ouso afirmar, assim, ser bastante complicado adentrar-me na busca por um conceito de narrativa e de narrador, sem falar do meu lugar de enunciação, que se mistura e se confunde com meu lócus de pesquisa.

É um espaço permeado por intensas dificuldades socioeconômicas, políticas e culturais. Todavia, nenhuma delas impediu o movimento de alguns de seus moradores na direção da academia, em busca de mudanças; ao contrário, o desejo de mudança veio desses tantos anos de injustiças sociais. Cinco foram os sujeitos que impulsionaram esta pesquisa, por acreditarem que outra "Tinga" é possível: Alex Pacheco, Jandira Brito, José Carlos dos Santos, o Beleza, e Marco Almeida, o Maragato, sendo, este último, nosso sujeito de pesquisa e foco desta explanação.

Aliás, é importante destacar ainda a nossa relação ${ }^{3}$ para com os moradores da Restinga, essa intervenção que perpassa pela criação de uma narrativa colaborativa, seja ela textual, seja ela literária, hiperficcional, na inscrição de Maragato como sujeito social. Por outro lado, tal reflexão se justifica à proporção

\footnotetext{
${ }^{2}$ A Restinga, mais conhecida por seus moradores como "Tinga", é o maior bairro de Porto Alegre, localizado ao sul da cidade. Foi criado pela Lei 6571 , de 8 de janeiro de 1990 . No entanto, sua origem remonta há algumas décadas antes e é marcada por uma série de remoções de moradores indesejados das áreas centrais da cidade, que tinham que ser "higienizadas" para dar lugar a espaços planejados, sinais do progresso urbano. A Lei de 30 de dezembro de 1965, que criou o Departamento Municipal de Habitação (DEMHAB), transferiu tais habitantes para um local $22 \mathrm{~km}$ distantes do centro de Porto Alegre: a Restinga.

${ }^{3} \mathrm{O}$ uso do eu e do que nós que se faz presente neste texto é proposital, na medida em que o mesmo advém de minha tese de doutorado intitulada "Das materialidades da literatura: a reinvenção da vida e o acervo de narrativas orais urbano-digitais", defendida em março de 2014 na Universidade Federal do Rio Grande do Sul e que foi parte integrante do projeto "A Vida Reinventada: pressupostos teóricos para análise e criação de acervo de narrativas orais". Tendo tido este projeto, entre um de seus objetivos, criar um acervo da memória do bairro Restinga e considerando que houve sempre uma relação entre os moradores da comunidade e os pesquisadores, não existe possibilidade de se trazer reflexões utilizando uma só pessoa verbal.
}

Texto Digital, Florianópolis, v. 10, n. 1, p. 76-101, jan./jul. 2014. ISSNe: 1807-9288 
que esbarra em mais uma das possibilidades de legitimação desses narradores que definimos como urbano-digitais.

Marco Almeida, o Maragato, é um "nômade cibernético". Essa categorização de nômade cibernético foi dada pela professora Ana Lúcia Tettamanzy, considerando o fato de que tanto Maragato está criando blogs, ministrando cursos na comunidade, como vendendo algodão doce ou puxando ferro (como ele mesmo diz, para se referir ao ofício de catar lixo) quando não há outras formas de sobrevivência. Cria programas de rádio, histórias em quadrinhos e ferramentas pedagógicas em ambiente digital, como veremos ao longo de nossa discussão.

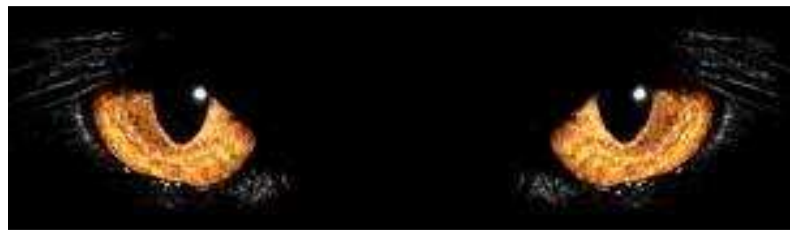

Fig. 1: Olhos de gato, marca registrada de Maragato

Tendo como marca registrada os olhos de gato, em função de, segundo o próprio, ter caído de muito alto e não ter se ferido (assim como o gato, que tem sete vidas), Maragato é poeta, artista plástico, produtor de programas de rádio e TV, pesquisador e desenvolvedor de ferramentas na internet, oficineiro de informática, rádio, TV e gibi digital, entre outras coisas. Gosta de fazer rádio, TV, filme e política. Tem lutado muito por aquilo que acredita, como uma educação digital de qualidade. Segundo costuma dizer, não olha para o passado, e sim para o presente, pois o passado já passou e o futuro está logo ali. Sonha em realizar TV escola na periferia. Pensar em literatura nos remete, em geral, ao registro textual, grafado em obras literárias canônicas. Todavia, e com base na experiência por mim vivida durante quatro meses no programa de Materialidades da Literatura, da Universidade de Coimbra, percebi, primeiramente, que justificar a narrativa oral urbano-digital a partir do conceito de poética, como geralmente é realizado, não se sustentava. Segundo que, com o suporte das teorias de hipertexto, é possível se falar em linguagem audiovisual, em internet, em imagens variadas, em pintura e gravura a partir da inscrição de todas essas manifestações artísticas num site da internet, sem perder de vista o conceito de objeto literário, independentemente 
de quem produziu4. Manuel Portela (2012, p. 10) na Introdução do volume 2 da Revista de Estudos Literários, afirma que a literatura, em seu caso particular, transforma os processos de escrita e leitura, colocando em causa a própria noção de materialidade literária.

A expressão "Materialidades da Literatura" quer, assim, designar a gama de possibilidades de explanação do literário, sem reduzi-la à mídia impressa.

Desse modo, uma das aberturas para as quais a referida materialidade pode levar é uma narrativa oral que se manifeste no ciberespaço (ou espaço virtual da internet $)^{5}$ e não perca o caráter que lhe é peculiar, ou seja, o de uma narrativa urbano-digital. O que seria tal narrativa? Quem a produz? Quem a acessa? É um sujeito letrado? Iletrado? Acadêmico? De que forma o faz? Quais categorias dos novos media estão imbricadas nesse ato narrativo? E quais os efeitos das narrativas produzidas com o suporte dos novos media, aqui designadas narrativas orais urbano-digitais, na academia e na sociedade como um todo? Tentemos fazer um percurso que possa nos levar às respostas às questões levantadas.

\section{A relação academia, periferia e narrativa: a remediação e o digital}

Jay Bolter e Richard Gruisin trazem, em sua obra Remediation: understanding new media, três conceitos capazes de explicar a relação academia-periferia: a remediação, a imediacia e a hipermediacia.

\footnotetext{
${ }^{4}$ Ter-se um site literário, independentemente de quem o produziu, dá conta daquilo que temos na Restinga e será melhor explicado ao longo do capítulo. Se aqui falamos de forma geral, sem citar diretamente o site "A Vida Reinventada", é porque esperamos ter, em nossa produção, um modelo para várias outras páginas internet, desenvolvidas nos mesmos moldes e com objetivos semelhantes - o reconhecimento das vozes da periferia.

5 Para Lucia Santaella, ciberespaço refere-se a todo e qualquer espaço informacional multidimensional que, dependente da interação do usuário, permite a este o acesso, a manipulação, a transformação e o intercâmbio de seus fluxos codificados de informação. Assim sendo, o ciberespaço é o espaço que se abre quando o usuário conecta-se à rede. Por isso mesmo, esse espaço também inclui os usuários dos aparelhos sem fio, na medida em que esses aparelhos permitem a conexão e a troca de informações. Conclusão: ciberespaço é um espaço feito de circuitos informacionais navegáveis. Um mundo virtual da comunicação informática, um universo etéreo que se expande indefinidamente mais além da tela, por menor que esta seja, podendo caber até mesmo na palma da nossa mão. (SANTAELLA, 2004, p. 45-6)

O ciberespaço é, portanto, o espaço de inscrição do narrador urbano-digital; é onde ele se legitimará a partir de uma série de produções hipermídia. A diferença entre hipertexto e hipermídia será explorada ainda neste capítulo.
}

Texto Digital, Florianópolis, v. 10, n. 1, p. 76-101, jan./jul. 2014. ISSNe: 1807-9288 
Os novos media digitais, para os autores citados, oscilam entre imediacia e hipermediacia, entre transparência e opacidade. Tal oscilação é a chave para entender como os media remodelam seus predecessores e outros media contemporâneos. Eles destacam que embora cada media prometa reformar seus antecessores, oferecendo uma experiência mais imediata ou autentica, a promessa de reforma vai, inevitavelmente, nos levar a tomar consciencia das novas media como mídias (BOLTER; GRUISIN, 2000, p. 21).

Muitos websites são aglutinações das diversas formas de media: gráficos, fotos digitalizadas, animação e vídeo - tudo pronto nas páginas cujos princípios de designer recaem no psicodélico dos anos 60 ou em 1910 e 1920. Misturar os media é, de alguma forma, uma intenção de tornar as notícias ou, em nosso caso, as histórias, mais perspicazes.

A remediação, ao contrário do que se pensa, não começou com os novos media: ela é um processo que surgiu ao longo dos últimos cem anos de representação visual do Ocidente. Uma pintura do século XVII, uma fotografia e um sistema computacional, quando colocados em contraponto pelos pesquisadores, não diferiram em muitos aspectos importantes, mas são tentativas de realização da imediacia, ignorando ou negando a presença dos media e do ato de mediação. Trazendo o conceito para a Restinga quando nós, por exemplo, transportamos um caderno do morador Beleza para o ambiente virtual ${ }^{7}$, passou por um processo de digitalização e também de remediação, por ter sido transformado do papel para megapixels e, por isso, vai ser lido de forma diferente por uma quantidade muito maior de pessoas. Assim, podemos entender remediação como uma nova roupagem que as velhas tecnologias ganham das novas. Ou, como afirmam Bolter e Gruisin (2000), a remediação pode ser entendida como a lógica formal pela qual as novas media repaginam, renovam as anteriores.

\footnotetext{
${ }_{7}^{6}$ Tradução minha.

7 Para ter acesso à imagem citada, acessar minha tese. Disponível em: $<\mathrm{http}: / /$ www.portaldepoeticasorais.com.br/site/?pg=textos\&id_categoria_textos=11>.
}

Texto Digital, Florianópolis, v. 10, n. 1, p. 76-101, jan./jul. 2014. ISSNe: 1807-9288 
Assim, a lógica das narrativas urbano-digitais, em especial as da Restinga, está nessa dupla (re)mediação, tanto no tocante aos objetos textuais que, quando passados para o site $^{8}$, ganham uma nova modelagem, quanto em relação à nossa participação enquanto grupo de pesquisa pertencente a uma instituição, já que somos (re)mediadores dos saberes dos moradores, cada vez que suas narrativas são inscritas em nosso site. Deste modo, a remediação é decomposta por Bolter (hipertexto 3.0) em três aspectos: primeiro, como mediação de mediação, isto é, como parte do processo através do qual os media se reproduzem e se substituem uns aos outros; segundo, como inseparabilidade entre mediação e realidade, que faz da mediação e dos seus artefatos uma parte essencial da cultura humana como realidade mediada; terceiro, como processo de re-forma da mediação da realidade, ou seja, como meio de transcender as formas e os meios de mediação anteriores.

Quanto à hipermediacia, cabe a ela ser um estilo de representação visual cujo objetivo é o de mostrar ao espectador/leitor todos os media que ele tem à sua disposição. É uma das estratégias utilizadas pela remediação.

Bolter e Gruisin (2000, p. 15) destacam o fato de que os primeiros capítulos da obra examinam o processo de remediação nos media contemporâneos. $\mathrm{Na}$ primeira parte, contextualizam o conceito de remediação dentro das tradições das literaturas atuais e da cultura literária, enquanto na segunda, ilustram a aplicabilidade dessa remediação em medias como computação gráfica, filme, televisão, world wide web e realidade virtual.

Outra consideração bastante interessante dos dois estudiosos está em assumirem que os novos media digitais participam da própria redefinição daquilo que se entende como cultura, já que nenhum media ou evento dos media parece, hoje, conseguir cumprir seu papel cultural isolada de outra midia, e nem trabalhar de forma isolada de outras forças sociais e econômicas. (Idem, ibidem) ${ }^{9}$

\footnotetext{
8 O site a que me refiro é 0 do projeto "A Vida Reinventada" (http://www.ufrgs.br/vidareinventada/site) por mim desenvolvido e que fez parte da minha tese de doutorado. A escrita do texto e do site aconteceram em concomitância.

${ }^{9}$ Tradução minha.
}

Texto Digital, Florianópolis, v. 10, n. 1, p. 76-101, jan./jul. 2014. ISSNe: 1807-9288 
As reivindicações dos teóricos acerca de imediacia, hipermediacia e remediação não se referem a que as mesmas sejam vistas como verdades universais, mas que sejam reconhecidas enquanto práticas de grupos específicos. A remediação sempre opera sobre os pressupostos culturais atuais acerca de hipermediacia e imediacia. A remediação, caracterizada a partir da hipermediacia e imediacia, é outro dos fatores que irão caracterizar as narrativas urbanas como literárias.
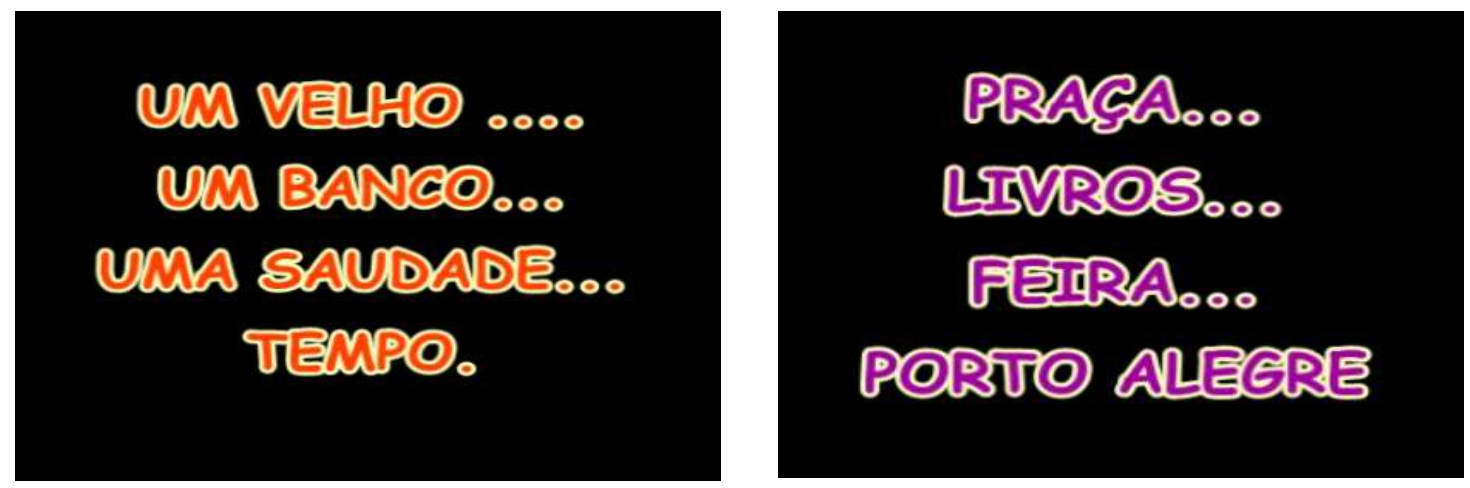

Fig. 2: Micro-histórias de Maragato

O texto imagético criado por Maragato parte de seu projeto "Micro-histórias", que coloca em tensão espaços visuais e reais; nos reais, está tudo aquilo que faz parte tanto dos sentimentos do autor quanto de seu posicionamento social face aos acontecimentos. A arte de Maragato vai ao encontro do que Lanham (1993 APUD BOLTER; GRUISIN, 2000, p. 41) chama de tensão entre olhar em e através e vê isso como uma característica da arte do século XX em geral e, agora, da representação digital em particular. Maragato enxerga através de olhos a reconhecer políticas que sempre marginalizaram as criações da periferia e, do seu lócus e daquilo que pensa poder mudar a partir do contato com seus pares, usa as janelas de que dispõe, as quais maneja com singularidade.

$\mathrm{Na}$ lógica da hipermediacia, o artista esforça-se para fazer o espectador reconhecer os meios como meio e encantar-se nesse reconhecimento. Faz isso por múltiplos espaços e pela repetida redefinição das relações visuais e conceituais entre os espaços mediados - relações que podem alcançar desde uma justaposição até uma completa absorção. (Idem, p. 41-2) 
Retomando a perspectiva da remediação, conceito amplo, que envolve os demais, é necessário destacar a frase de abertura do já citado Understanding Media (1964), em que McLuhan reitera que o conteúdo de qualquer meio é sempre outro meio. O raciocínio do estudioso vai em direção a uma forma mais complexa de empréstimo na qual um meio é representado e incorporado em outro meio. Para Bolter e Gruisin, a representação de um meio em outro é a remediação e a remediação é a característica definidora dos novos media digitais. Além disso, a remediação está entre os conceitos que, aliados às ferramentas hipermidiáticas, às diversas formas de manifestação e intervenção do (em/para com o) sujeito, nos permite aceitar a existência de uma narrativa oral urbana capaz de se inscrever e legitimar em ambiente virtual. Isso faz ainda mais sentido se pensarmos que a remediação entende que o velho meio, ou seja, o meio primeiro de onde vem determinada narrativa/produção não pode ser inteiramente acabado e cabe aos novos media permanecerem dependentes dos velhos em caminhos reconhecíveis ou irreconhecíveis. Assim, quando Maragato traz seu trabalho nas escolas para o ambiente digital, há uma narrativa primeira, com objetivos específicos e conscientes, que dará origem a várias novas narrativas. $O$ mesmo ocorre quando funde recursos literários contemporâneos - como o microconto ou a micronarrativa - às suas micro-histórias na rede. A intervenção de Maragato para com o leitor dá-se, também, a partir da internet, visto que, após suas oficinas nas escolas, ele enviava ao grupo de pesquisa um tipo de relatório, descrevendo os resultados de sua atividade. ${ }^{10}$

O processo de remediação, assim, é uma "via de mão dupla" e acontece, no âmbito desta análise, em três momentos: da academia para com o sujeito de pesquisa, desse sujeito para com os seus pares e do sujeito para com a academia,

A hipermedia passa por dois paradoxos: 1) hipermedia jamais poderia ser pensada como ferramenta de alcance do imediável; 2) hipermedia luta por imediacia; as tecnologias digitais transparentes sempre terminam sendo

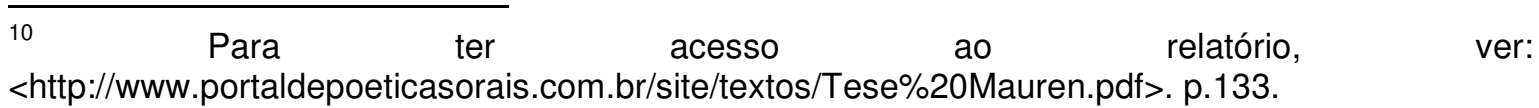


remediações, assim como, na realidade, elas parecem precisamente negar a mediação, conforme se colocam como única verdade proferida, esquecendo, muitas vezes, de onde surgiram.

Todavia, o ápice do pensamento de Bolter e Gruisin (2000, p. 55-6) (Grifos do autor $)^{11}$ está naquilo que os autores chamam de dupla lógica da remediação; são estratégias pelas quais cada meio digital remedia e é remediado pelos seus predecessores. Funcionam implícita e explicitamente e podem ser iniciadas por diferentes caminhos seja como remediação como mediação da mediação em que cada ato depende de outros atos de mediação e no qual os media são continuamente comentados, reproduzidos e substituem outros; os medias tem uma interdependência a qual está atrelada seu funcionamento; remediação como inseparabilidade da mediação e da realidade na qual, mesmo que a noção de Baudrillard de simulação e simulacro possa sugerir o contrário, todas as mediações são em si reais como artefatos em nossa cultura mediada. Ainda que saibamos do fato de todos os media dependerem de outros media, em ciclos de remediação, nossa cultura ainda precisa reconhecer que todos os media remediam o real. Como não podemos nos livrar da mediação, não podemos nos livrar do real; Remediação como reforma que objetiva remodelar ou reabilitar outros media. Considerando, assim, que todas as mediações são reais e, deste modo, mediações do real, a remediação pode ser também entendida como um processo de reforma da realidade.

Assim, fica claro que a remediação não existe como conceito único, estanque; ela depende de atos de mediação para acontecer. Além disso, os elementos remediados são simulacros, representações diferidas do real, fazem parte de processos de reforma da realidade, uma remodelagem dos processos anteriores ou, ainda, segundo Beatriz Martins (2012, p. 21), uma relação dialética com outras linguagens, na medida em que esta dialética inclui, também, um movimento na direção contrária: os meios antigos, por sua vez, estão em constante recriação, tomando emprestado alguns traços dos emergentes a fim de se manter atualizados e fazer frente às novas linguagens.

\footnotetext{
${ }^{11}$ Tradução minha.
}

Texto Digital, Florianópolis, v. 10, n. 1, p. 76-101, jan./jul. 2014. ISSNe: 1807-9288 
Jean Baudrillard (1991), em sua obra Simulacro e Simulação, retoma a já vista fórmula de MacLuhan Medium is message afirmando que

\begin{abstract}
Numa palavra, Medium is message não significa apenas o fim da mensagem, mas também o fim do medium. Já não há media no sentido literal do termo (refiro-me sobretudo aos media eletrônicos de massas) isto é, instância mediadora de uma realidade para uma outra, de um estado real para outro. Nem nos conteúdos nem na forma. [...] (BAUDRILLARD, 1991, p. 107-8)
\end{abstract}

Ou seja, é difícil tecer uma diferenciação entre os media e o real: ambos se misturam na constituição de novas formas de pensamento, que bem podem ser exteriorizadas em formas de narrativas. Essa talvez possa ser considerada a chave negativa do simulacro, quando se pensa a representação das histórias de vida, das narrativas, a partir de sua inscrição no meio digital.

Entendendo as narrativas orais urbano-digitais como um simulacro; essa pesquisa atesta uma supressão do real que deixa lacunas, as quais podem ser preenchidas pela interpretação de quem a recebe, pela crítica que pode ocorrer acerca da norma não padrão de língua utilizada ou mesmo pela não aceitação de que um sujeito periférico possa, ignorando suas dificuldades de escrita, provocar as instituições na figura de professores, pesquisadores ou mesmo alunos.

Assim, a remediação nos levou a pensar em narrativas que ganharam novas roupagens e faz-se necessária, agora, uma breve definição acerca da narrativa digital para, em seguida, chegarmos em quem a produz: o narrador.

\title{
I. 3 Do conceito de narrativa digital hiperficcional
}

Ao pensarmos em sua definição, a narrativa digital nos remete, em primeiro lugar, a uma simples passagem do escrito para o formato eletrônico, ou a um tipo de registro criado a partir de funções determinadas exclusivamente para o uso em meio eletrônico. Entretanto, ela é muito mais do que isso: é uma forma de inscrição das ideias de um sujeito no mundo. 
Marie-Laure Ryan (2001) propõe dois principais critérios para a classificação da forma de expressão "narrativa digital". Em primeiro lugar, ela deve ser uma narrativa que faz a diferença quanto ao tipo de mensagens que transmite, como essas mensagens são apresentadas ou como são experenciadas. Além disso, deve apresentar uma combinação única de características, que podem advir das seguintes áreas: 1) o sentido da abordagem; 2) a prioridade dos canais sensoriais (assim, a ópera poderá, por exemplo, ser considerada um tipo distinto do drama, mesmo que os dois meios de comunicação incluam as mesmas dimensões sensoriais. A ópera dá maior prioridade ao canal de som do que o drama); 3) a extensão espaço-temporal; 4) o apoio tecnológico e a materialidade dos sinais (pintura contra fotografia, discurso contra escrita contra codificação digital da linguagem), (e) o papel cultural e métodos de produção/distribuição (livros versus jornais). ${ }^{12}$ Em seu livro Narrative as Virtual Reality, ela propõe definir o termo Narração virtual, como uma evocação de eventos de resistem à expectativa de realidade inerente à linguagem em geral e, também, à discursiva em particular. [...] No tipo de narrativa que chamo real, o narrador apresenta proposições como verdadeiras, e a audiência imagina os fatos (estados ou eventos) representados por essas proposições. $(2001 \text {, p. 163) })^{13}$

Assim, pensar na narrativa digital, no caso do Maragato, nos demanda a associação com uma narrativa hiperficcional, o que justifica o caráter literário de suas produções. A hiperficção tem a característica de mostrar como a base de dados é capaz de alterar a narrativa. Normalmente, numa produção ficcional tradicional, temos uma única sequência de acontecimentos e, portanto, ao ler uma história tradicional, é fácil percebermos seu início, meio e fim. Dentro de meu próprio ato de leitura, já há uma ordem discursiva, uma ordem de leitura, de história, de mundo a ser representada; uma sequência cuja organização é fortemente narrativa, na qual todos os elementos derivam uns dos outros e relacionam-se entre si a partir de uma associação causa-efeito, anterioridadeposteridade, espaço/lócus.

\footnotetext{
${ }^{12}$ Disponível em: <http://www.imageandnarrative.be/inarchive/mediumtheory/marielaureryan.htm>. Acesso em: 18 mar. 2013. Tradução minha.

13 Tradução minha.
} 
Enquanto a narrativa tradicional constrói-se dessa forma, a hiperficção segmenta a narrativa em itens, lexias, fragmentos de texto e, depois, permite que o leitor possa percorrê-los na ordem que pensar ser mais conveniente. Nesse momento, o que o leitor faz nada mais é do que transformar a narrativa em uma base de dados, a partir de sua segmentação, e, com base na sua leitura, construir a própria narrativa por meio desse movimento modificador. Assim, a organização temporal da narrativa será repleta de paradoxos; muitas vezes, encontramos nela fragmentos que tornam vivo um personagem que tinha morrido, uns anteriores ou posteriores a outros, pois, do ponto de vista temporal, de lógica do espaço ou de causa e efeito, quando segmentamos a narrativa, nós a transformamos em um conjunto de itens possíveis de serem percorridos das mais diversas formas, criando, assim, uma outra maneira de produzir narrativa, mais permutável.

A cultura computacional fomenta a base de dados e esta tem um princípio de organização diferente daquele da narrativa, o qual, no entanto, pode dar origem a processos narrativos. Exemplo disso está na hiperficção, visto ser ela, ao fim e ao cabo, uma forma de organizar determinada narrativa em uma estrutura de base de dados na qual o leitor vai lendo fragmentos e, depois, construindo ligações entre esses fragmentos, que podem não estar dadas. A construção das lógicas narrativas, muitas vezes, passa para o lado do leitor, em vez de estar tanto ao lado do texto; há ligações que o leitor vai inventar ou descobrir, que dependem da ordem de leitura a ser seguida por ele.

Segundo Ana Rita Duarte (2007), hiperficção é a "narrativa desenvolvida segundo uma estrutura em labirinto, assente na noção de hipertexto, ou texto a três dimensões no hiperespaço, em que a intervenção do leitor vai determinar um percurso de leitura único que não esgota a totalidade dos percursos possíveis no campo de leitura"14. Sendo a produção de Maragato, preocupada com a participação do leitor, seja ele um membro do grupo de pesquisa ou mesmo um aluno de uma de suas oficinas, ela é, sim, uma narrativa hiperficcional, já que é submetida diariamente por um processo de construção e desconstrução.

\footnotetext{
14 Hiperficção: "My Body" by Shelley Jackson. Disponível em: <http://diglitmedia.blogspot.com.br/2007/05/hiperfico-my-body-shelley-jackson.html>. Acesso em: 6 mar. 2013.
}

Texto Digital, Florianópolis, v. 10, n. 1, p. 76-101, jan./jul. 2014. ISSNe: 1807-9288 
Na hiperficção ${ }^{15}$, o texto perde a sua dimensão, a ordem espacial e temporal, não possui uma lógica, um compasso sequencial. A leitura da obra, definitiva e universal, não existe a priori, mas é construída gradual e individualmente a partir das opções que o autor sugere, embora precise ficar claro que, a partir do momento em que uma obra é publicada no ambiente digital, o autor aceita sua perda de controle sobre a mesma. A esse respeito, nos chama a atenção Lúcia Leão (2005), que o hipertexto faz do leitor um pouco escritor na medida em que, ao navegar pelo sistema, ele vai estabelecendo elos e delineando tipos de leitura. O leitor-ativo que a hipermídia requisita é, para a autora, o "arquiteto de um labirinto). O viajante, ao percorrer o sistema, faz existir um espaço que se desdobra. No momento em que este atualiza escolhas, o desenho de um labirinto é criado (2005, p. 46).

Nesse tipo de criação, apresentam-se várias possibilidades de continuação, não existem regras específicas, nem linearidade, princípio ou fim; daí a grande importância do leitor como máquina decifradora e construtora de sentido, possivelmente, o detentor do plano mais importante: completar e interpretar. Segundo Dênis de Moraes (2007), os hyperlinks reordenam a estrutura narrativa e a arquitetura ficcional, bem como dinamizam os itinerários de leitura e interpretação. O que é sólido pode ser também móvel, fluido, desenraizado e acessível a qualquer segundo, ${ }^{16}$ e o texto passa a ser atualizável a partir do virtual, fazendo, assim, com que nasça um novo tipo de leitor: interativo, que sabe usar a tecnologia a seu favor e é capaz de usar o seu processo criativo para construir narrativas em hipertexto.

Espen Aarseth (1997, p. 77) afirma que a literatura hipertextual (em seguida denominada hiperficção) não tem que responder aos problemas práticos enfrentados pelo hipertexto não literário; ou ainda que é livre para responder em

\footnotetext{
15 Disponível em: <http://diglitmedia.blogspot.com.br/2007/05/novas-frmulas-digitais-dohipertexto.html>. Acesso em 6 mar. 2013.

${ }^{16}$ Revista Ciberlegenda, num 3, 2000. Disponível em: <http://www.uff.br/mestcii/denis5.htm>. Acesso em: 6 mar. 2013.
}

Texto Digital, Florianópolis, v. 10, n. 1, p. 76-101, jan./jul. 2014. ISSNe: 1807-9288 
um caminho literário, pondo em primeiro plano questões de mímese e narrativa da maneira que é esperada pelo trabalho literário artístico.

É o que, em certa medida, diz Manuel Portela (2003, s. $p^{17}$ ) e que podemos perceber com a retomada de suas reflexões.

\begin{abstract}
Num certo sentido, o hipertexto criaria uma representação similar da criação, transmissão e uso dos textos, justamente pela sua natureza meta-informativa. Esta representação de segunda ordem da forma bibliográfica destrói a unidade discreta do códice e reconstela os seus elementos num espaço discursivo mais vasto e variável. A ordem imposta pelo códice ao conhecimento e à experiência refaz-se num hiperlivro virtual, cujas fronteiras discursivas e materiais deixaram para sempre de poder repetir as fronteiras do livro tipográfico. Considerada como hiperedição, hiperpoesia ou hiperficção, a literatura cibernética altera as práticas de leitura e de escrita, altera os géneros e as formas, altera mesmo o conhecimento da história literária e da semiose literária em geral. ${ }^{18}$
\end{abstract}

Assumindo que a narrativa hiperficcional é um tipo de literatura hipertextual e que sua construção é mimética, então, podemos entender as narrativas urbanodigitais como fazendo integrantes de uma classificação literária. Isso porque aquilo que os narradores urbano-digitais criam nada mais é do que uma narrativa ficcional, inscrita, no caso de Maragato, na web e de caráter subjetivo.

Nesse ínterim, de pensar num conceito de literatura atrelada ao hipertexto, Regina Corrêa (2006) reflete acerca das tentativas de se determinar o que é literatura, como elas conduzem a uma percepção de literatura enquanto arte, criação e imaginação a partir do momento em que ela pode ser considerada uma reflexão e uma recriação da realidade, sendo essas últimas características bastante presentes na produção de Maragato. Sobre o texto, a autora destaca que ele pode ser definido como literário com base na forma como os temas são abordados e não pelo que propriamente tratam, já que as tentativas de determinar

17 O Hipertexto como Metalivro. Disponível em:
<http://www.ciberscopio.net/artigos/tema2/clit_05.html>. Acesso em: 20 mar. 2013. Quanto a esse e aos demais artigos com palavras grafadas em português de Portugal, optei por manter a grafia original. Disponível em: <http://www.ciberscopio.net/artigos/tema2/clit_05.html>. Sem número de página. 
o que é literatura irão conduzir sempre a uma percepção de literatura como arte, criação e imaginação. Assim, não pode ser vista como retratação da realidade, mas como reflexão, recriação do real.

\begin{abstract}
Um texto também não pode ser definido como literário a partir dos temas retratados, e sim a partir da forma como os temas são abordados. No entanto, a simples classificação de um texto como literário não é o bastante para que se possa valorizá-lo em termos qualitativos. Existem vários outros fatores, dentre eles os históricos, religiosos, políticos. [...] A publicação de uma obra literária de forma independente pode ser feita quase de graça, através de cds e/ ou sítios na Internet. Estas formas de publicação têm proporcionado tanto aos escritores quanto aos leitores uma maior rapidez de contato e uma maior proximidade, visto que os textos, bem como as opiniões dos leitores circulam muito rapidamente. Assim, se a questão antes se concentrava basicamente na definição do que é ou não é literatura e em problemas de estilo, agora as discussões assumem novos rumos com ênfase na construção, leitura e análise de textos muito mais complexos, como o hipertexto ou os textos literários construídos on-line. (CORRÊA, 2006, p. 32-3) ${ }^{19}$
\end{abstract}

Se retomarmos a perspectiva já citada por Manuel Portela, o que essa narrativa urbano-digital quer é, por meio de um olhar hiperficcional, dar uma nova roupagem às tantas histórias de tantas vidas que a cada dia estão a se reinventar. A hiperficção é, portanto, uma nova forma de representação da literatura, a qual, via tecnologia, pode ser lida de diversas formas, pelos tantos objetos mediáticos, os quais, unidos, darão origem a outras inúmeras narrativas em que, menos que o estilo, importa o como os temas são abordados.

\title{
3.1 Do narrador urbano-digital: a narrativa interativo-ficcional de Maragato
}

Para entender os narradores urbano-digitais, é preciso saber que uma das grandes características de sua produção reside no caráter ficcional interativo; são narrativas que surgem de uma interação entre moradores, de uma troca de experiências que também depende da interação para se legitimar. Elas têm, como princípio, portanto, o fato de não estarem acabadas, dependerem da interação que o leitor/usuário irá fazer. Assim, não podemos dizer que qualquer relação entre dois elementos cria uma narrativa; há critérios para defini-la. Carlos Ceia,

\footnotetext{
${ }^{19}$ As sentenças em inglês presentes no interior da citação foram escolhas da autora, que eu decidi manter.
}

Texto Digital, Florianópolis, v. 10, n. 1, p. 76-101, jan./jul. 2014. ISSNe: 1807-9288 
no E-dicionario de termos literários, tece um paralelo entre narrativa e narratividade. Diz o autor:

\begin{abstract}
Efectivamente, a narrativa é um lugar codificado onde uma história é redimensionada temporal e espacialmente e onde os eventos e as acções são submetidas à alquimia da linguagem a fim de se tornarem em objectos estéticos. Em última análise, a narratividade exerce uma força modalizante na narrativa que a conduz a uma integração históricosocial. Por isso, os textos das diferentes épocas foram lidos diversamente através da história e pelas diferentes classes sociais, podendo dizer-se que a narratividade de cada texto determinará a sua recepção pelo variado público. [...]

Neste contexto, a narratividade está numa relação directa com o receptor, pois é nele que se irá realizar o fenómeno estético da arte em geral, donde se pode considerar que a narratividade ocupa uma posição funcional na narrativa e é o processo pelo qual o receptor constrói activamente a história a partir da matéria narrativa fornecida pelo meio narrativo. Uma vez que a narrativa representa uma reconstrução do universo que todos os dias se faz de forma diferente, a narratividade deve ser entendida como uma qualidade do discurso reconstrutor desse universo e ser actualizada pelo processo da leitura. $(2010, \mathrm{~s} / \mathrm{p})^{20}$
\end{abstract}

Visto que a narrativa de Maragato é plena dessas forças modalizantes que conduzem a uma integração histórico-social e ao passo que é trazida para o meio acadêmico, em congressos e seminários e também é lida por diferentes classes sociais, ela possui o caráter de narratividade necessário para ser considerada como legítima.

A narrativa urbano-digital é, assim, uma produção que parte de um discurso desconstrutor daquilo que se conhece como universo da periferia e se atualiza a cada acesso; cada novo visitante de um dos sites de Maragato, ou participante de sua oficina, com as experiências prévias e as produções, é um leitor e modifica o sentido do narrado.

A ficção interativa é um tipo de narração que permite ao leitor/usuário uma visão não linear, fazendo-Ihe um convite a interagir com o que está sendo contado. A interação, no caso de Maragato, acontece, também, na sala de aula, no momento em que ele demonstra como funciona um site de produção de histórias em quadrinhos e pede que seus alunos criem as suas próprias, apoiados na 20 em: <http://www.edtl.com.pt/index.php?option=com_mtree\&task=viewlink\&link_id=68\&ltemid=2> Publicado on-line, sem número de página disponível. Acesso em: 8 fev. 2014.

Texto Digital, Florianópolis, v. 10, n. 1, p. 76-101, jan./jul. 2014. ISSNe: 1807-9288 
assistência aos vídeos, que podem despertar o interesse em criar outros vídeos ou projetos semelhantes, ou na forma mais básica de interação: a que leva ao contato com o autor em função do interesse em alguma de suas publicações eletrônicas.

Jay Bolter, em Writing Space, ao pensar na escrita eletrônica, acrescenta que a ficção eletrônica não precisa ser automática ou gerada por computador, já que o computador ao invés de criar o texto verbal, apresentará o texto ao leitor de acordo com as pré-condições do autor.

O leitor pode ter que escolher entre algumas alternativas ou pode explorar amplamente o trabalho. Cada autor pode abdicar de mais ou menos controle conforme sua escolha: ela simplesmente tem uma outra dimensão literária com a qual trabalhar. (Idem, p. 123-4) ${ }^{21}$

Assim, percebe-se que a narrativa interativa não está toda terminada: ela irá depender da interação que ocorrerá entre leitor e usuário, já que permite, em sua estrutura, uma certa liberdade de leitura ${ }^{22}$. Todavia, não é suficiente apenas criar trajetórias de leitura a partir de sugestão de links a serem percorridos. Não podemos dizer que qualquer relação entre dois elementos cria uma narrativa. Há critérios para definir uma narrativa. A narratividade que podemos encontrar numa narrativa interativa, em parte, é uma narratividade já concebida pelo próprio autor, ou seja, ele já deu potencialidade a certos elementos para eles se transformarem em uma história, ainda que a mesma dependa do percurso que o usuário irá fazer. Em termos de predominância, uma narrativa tem o predomínio de certo tipo de modos de representação: um texto descritivo tem o predomínio de certos modos de representação; um texto argumentativo, a mesma coisa, o que não significa a impossibilidade de haver, em um texto argumentativo, alguns elementos narrativos; no fundo devemos pensar o problema em termos de predominância. Um discurso político ou um texto que seja uma descrição técnica

\footnotetext{
${ }^{21}$ Tradução minha.

${ }^{22}$ Alice Bell (2011), com base nas ideias de Douglas, em seu artigo "What hipertextes can do that print narratives cannot", afirma que "nas narrativas impressas nossas experiências de leitura começam com as primeiras palavras da narrativa e é completada pelas últimas palavras da última frase. (1992, p. 2). A rigidez da impressão e a escassez da escolha em que Douglas acredita oferece um contraste com a aparente liberdade que o hiperlink permite". (BELL, 2011, p. 64)
}

Texto Digital, Florianópolis, v. 10, n. 1, p. 76-101, jan./jul. 2014. ISSNe: 1807-9288 
de um objeto até podem ter alguns elementos narrativos, mas não são narrativas, não são histórias, no sentido estrito do texto.

A ideia de que todas as representações verbais são narrativas acaba por destruir o conceito de narrativa. Por isso que Manovich (2001) chama atenção para o fato de que a possibilidade de um texto, de uma obra, ser considerada narrativa interativa não depende só do usuário. Devemos tentar manter a especificidade do conceito de narrativa e tentar entender o que o meio digital faz, isto é, uma das coisas que o meio digital faz é construir outros modos de produzir narrativa. A ideia de que o meio digital é predominantemente construído por base de dados não aponta a inexistência de formas narrativas nesse meio. Na realidade, o que acontece é que nós encontramos formas narrativas cujo fundamento é uma base de dados. Uma das formas pelas quais o meio digital transforma a narrativa é precisamente criando narrativas fundadas em bases de dados.

\begin{abstract}
As ligações são o elemento essencial das narrativas electrónicas, permitindo gerar percursos recursivos ou divergentes, que concretizam os princípios não-deterministas do hipertexto. A inerente instabilidade textual e gráfica do texto electrónico tem sido também uma característica destacada para o distinguir da fixidez do texto tipográfico. De igual modo à unicidade da página impressa opor-se-ia a multiplicidade das interfaces hipertextuais. Mas estas distinções não se poderiam de facto alargar ao nível do código máquina, pois a este nível haveria sempre uma sequência electrónica armazenada para cada pedaço de informação. Isto significa que sob o ponto de vista da materialidade electrónica não seriam de facto menos estruturados e fixos, apesar das múltiplas configurações textuais e gráficas que poderiam assumir, de acordo com as plataformas, aplicações e interfaces de apresentação e manipulação. (PORTELA, 2003, s.p) ${ }^{23}$
\end{abstract}

Por tudo isso, Maragato produz um novo tipo de narrativa: a narrativa urbanodigital hiperficcional; uma narrativa que tem na mímese (ou seja, na representação de ideias e em suas práticas do dia-a-dia em oficinas nas escolas ou em seus blogs, por exemplo), na hiperficção e na interatividade elementos que a legitimam. Suas histórias têm um porquê e o caráter social, político e econômico são também definidores desse novo tipo de produção. O som, o vídeo, o áudio e todos os demais elementos hipermídia fazem parte da composição dessa narrativa urbano-digital. Se aqui tratamos da Restinga, sabemos que nosso país

${ }^{23}$ Op. cit nota 24, p. 19.

Texto Digital, Florianópolis, v. 10, n. 1, p. 76-101, jan./jul. 2014. ISSNe: 1807-9288 
está repleto dessas narrativas urbano-digitais, vistas, na maioria das vezes, como produções advindas de indivíduos pouco capazes de produzir algo que contenha qualidade estética. A estética em ambiente digital está presente na interface do site, mas está também no posicionamento social que ele carrega, na fala de seus narradores.

A narrativa urbano-digital é colaborativa e plural: não se faz apenas por uma pessoa, mas por várias vozes que possuem sede de mudança e estão subjacentes a que produz e publica. Vários maragatos fazem parte de um Maragato. Ao criar um livro de poesia chamado JK no país das calças beges há, certamente, uma intenção política por trás do título, muito embora o autor diga que foi algo que "saiu de sua cabeça no momento em que precisava de um título".

\subsection{Amarrando nós: a narrativa oral urbano-digital de Maragato}

Leão (1999) retoma as ideias de Bolter (1990), em seu artigo intitulado "Topographic writing: hypertext and the eletronic writing space", dando destaque à reflexão acerca da natureza da escrita. A pesquisadora enfatizará o conceito de hipertexto para pensar os conceitos de escrita topográfica e hierarquia em ambiente hipertextual, tão caros a este artigo, no intuito de se chegar a uma consistente definição de narrador oral urbano-digital. Diz a autora:

Para Bolter (1990, p.114), o hipertexto é uma "rede de elementos simbólicos interconectados interativamente". A "escrita topográfica, por sua vez, é aquela na qual se divide o texto em unidades, os tópicos, de tal forma que se possa, num outro momento, organizar essas unidades numa estrutura coerente.

Marcelo Souza (2010), em seu trabalho intitulado "Narrativa Hipertextual Multimídia: um modelo de análise"24 destaca, que

A narrativa traduz o conhecimento objetivo e subjetivo do mundo (o conhecimento sobre a natureza física, as relações humanas, as identidades, as crenças, valores e mitos, etc.) em relatos. A partir dos 
enunciados narrativos somos capazes de colocar as coisas em relação umas com as outras em uma ordem e perspectiva, em um desenrolar lógico e cronológico. É assim que compreendemos a maioria das coisas do mundo. (MOTTA, 2005, p. 2 APUD SOUZA, 2010, p. 42)

Chegamos aqui a um ponto crucial e a um momento-chave, em que podemos afirmar categoricamente ser a produção de Maragato uma narrativa. Suas histórias em quadrinhos, por exemplo, podem ser consideradas eventos conectados, causados ou experimentados pelos atores. Esses últimos são, no contexto da presente análise, seus alunos, seus parceiros, todos aqueles que, em algum momento, passam a fazer parte da sua história de vida e são registrados em sua produção. Além disso, o que Maragato produz é uma forma de organização de sua existência, de sua relação com seus parceiros, de suas crenças e valores. Vejamos suas micro-histórias, publicadas no blog $<$ http://exposicaoviacrucis.blogspot.com.br/> ${ }^{25}$

Assim, e se a narrativa tem como uma de suas funções explicar a maioria das coisas do mundo, então, o que Maragato produz é uma narrativa, inscrita em ambiente digital e cujo cenário é a urbanidade.

\section{Para concluir...}

A revolução tecnológica transformou o modo pelo qual os sujeitos se inscrevem no mundo. Antes, a literatura era consumida apenas por quem tinha o domínio da escrita; agora é para quem, além desse domínio, explora o ambiente digital.

A constituição do acervo digital foi a mola propulsora no sentido da quebra de paradigmas. Não só as narrativas tradicionais podem ser produzidas por sujeitos que não estão necessariamente na academia, como também as digitais. Aliás, o meio digital, nesse sentido, é bem mais democrático, e a dificuldade está em se reconhecer como legítimas produções advindas de meios menos privilegiados. A periferia, por sua vez, é o lócus de surgimento do narrador oral urbano-digital,

\footnotetext{
${ }^{25}$ Este blog deveria ser, a princípio, um meio de divulgação da já citada exposição "A Via Crucis da Restinga em 12 estações"; no entanto, Maragato passou a utilizá-lo como mais um espaço de divulgação de suas produções.
}

Texto Digital, Florianópolis, v. 10, n. 1, p. 76-101, jan./jul. 2014. ISSNe: 1807-9288 
aquele que utiliza os recursos que estão ao seu alcance para ser o disseminador de sua voz e da de seus pares. Nem todos possuem tal domínio, obviamente, mas é preciso entender que, tanto na academia quanto fora dela, existem sujeitos que se destacam, sobretudo por sua capacidade de interação com os demais sujeitos e com as tecnologias, mesmo sem possuir os recursos que seriam necessários à realização desse tipo de tarefa. Maragato é este sujeito. Suas ações, no período em que a pesquisa foi realizada, foram voltadas, sobretudo, para a Restinga. Maragato foi apenas um exemplo. Existem muitos maragatos nos mais diversos espaços sociais.

Regina Carmela e Cristina Haguenauer (2012, p. 56), ao tecerem um paralelo acerca do contador de histórias e das narrativas digitais, afirmam que se antes a "ressignificação advinha da relação presentificada do contador/ouvinte, no panorama atual estabelece-se o paradoxo presença/ausência, presencial/virtual".

A afirmação nos é significativa pelo fato de o narrador oral urbano-digital ser esse sujeito contador de histórias que, procurando um lugar de aceitabilidade para suas narrativas, o encontra nessa presença/ausência o que o ambiente digital possibilita. O narrador pode trazer à tona sua voz narrativa, mas a recepção que isso terá não pode ser controlada. Sua presença não é vista porque ela só existe no momento da publicação. Aquilo que foi escrito se transforma pela perspectiva de cada usuário. O presencial e o virtual, nesse sentido, se confundem, na medida em que suas ideias são virtualizadas e passam a integrar um ambiente que abrange milhões de pessoas, as quais podem concordar ou não com o olhar dado sobre determinada narrativa.

A mediação, tal qual entendida aqui, concretizou-se na medida em que se conseguiu publicar no site $A$ Vida Reinventada a produção dos moradores da Restinga e também, estabelecer uma relação de confiança e troca com Maragato. Atualmente, o meio de comunicação mais utilizado por ele é o Facebook. A rede social, torna-se, assim, remediadora das ideias, presentes também em blogs e emails, já que a remediação está nesse processo de passagem de um meio a 
outro. É a mediação no sentido político e de saber e a remediação no de documento hipermidiático e hiperdigital.

Assim, como meu objetivo foi o de comprovar a existência desse narrador oral urbano digital, acredito que o acervo do projeto $A$ Vida Reinventada e a produção de Maragato se misturam, por ele fazer parte do acervo e por constituírem elementos comprobatórios da existência dessa categoria narrativa. O narrador oral urbano digital nada mais é do que um remediador de saberes plurais periféricos. A remediação, no sentido mais amplo do termo, ocorre conforme, por exemplo, ele lê o trecho de um livro ou se depara com uma história e decide publicá-la em seus já citados blogs, sites, quando ele monta uma história em quadrinhos, a partir do contato com a coordenadora do projeto e/ou algum dos membros etc. Assim, o que melhor define o perfil de Maragato como remediador é o fato de ele circular bem entre diversos meios hipermídia, o que confere o caráter digital à sua narrativa.

A remediação de Maragato se faz presente, sobretudo, na sua facilidade de interação com a academia, no momento em que participa de eventos, interpelando as pessoas e também no seu diálogo com a comunidade, tornando-a uma verdadeira sociedade em rede, aos moldes do que disse Castells (2005). É dela que surgem as histórias e as subjetividades pelas quais ele luta e que descreve em suas publicações. Maragato, muitas vezes, se define como pesquisador; em grande parte do tempo é um narrador e sempre um provocador. Ele tensiona o tempo todo a realidade, a nossa relação para com os moradores da Restinga e os resultados que tudo isso pode, de fato, ocasionar. Por outro lado, os anos de convívio estabeleceram uma parceria que vem da confiança e dos resultados já demonstrados (nos vídeos, no site e nos encontros).

Isso posto, é preciso enfatizar que existiram dois focos de análise: um baseado no acervo e outro, na produção em geral de Maragato. No primeiro, a escolha dos materiais passava pela discussão prévia com os colegas da pesquisa e com a orientadora. É a nossa visão enquanto pesquisadores e a partir das vivências em campo. Todavia, sempre foi levado em conta aquilo que escutávamos nas idas a

Texto Digital, Florianópolis, v. 10, n. 1, p. 76-101, jan./jul. 2014. ISSNe: 1807-9288 
campo. A produção bastante diversificada de Maragato se faz presente desde 0 início desta tese e não se deteve apenas àquilo que escolhemos para compor o acervo, mas abrangeu todo o material encontrado nos sites de busca e de possível acesso.

Penso que estes também foram os dois momentos que melhor puderam descrever a minha tarefa enquanto mediadora e a forma como a mediação foi realizada. A primeira mediação foi em relação ao site, o que se tornaria menos complicado por ser discutido com outros pesquisadores e a segunda que foi trazer para o papel uma produção a qual, por vezes, faz muito mais sentido no contato, se pensarmos em um programa de rádio, em um vídeo. A força do discurso de Maragato pode ser muito melhor compreendida no contato direto.

Objetivei, com esta pesquisa, ampliar o campo dos estudos literários a partir do estabelecimento de um novo conceito e de um novo olhar sobre a narrativa: o da existência de um narrador oral urbano digital, um sujeito presente em um mundo que não necessita apenas do papel, da história contada, da internet, da imagem para que uma narrativa se estabeleça, mas que pode encontrar uma narração muito interessante na junção de todas, a partir do que se conhece como hipermídia.

Estabelecer o conceito de narrador oral urbano digital em muito está relacionado com o fato de as histórias de Maragato serem eventos narrativos que possibilitam a ligação entre fatos, acontecimentos, perspectivas, cronologias. Sabe-se que falar em ambiente digital e em cronologia não parece algo que faça sentido, mas aqui houve uma intenção, por parte do narrador, de trazer fatos cronológicos para a sua publicação. A lógica e a cronologia da recepção dependerão, obviamente, de quem lê.

À guisa de conclusão, cabe a nós, pesquisadores do campo dos estudos literários, apostarmos em novos narradores, que possuam uma vasta produção narrativa e não estejam necessariamente na academia. É preciso abrir o olhar para produções narrativas não acadêmicas, mas que podem intervir no meio, 
tendo, assim, um olhar científico sobre as narrativas orais que, apesar de influenciadas por toda a forma de progresso, persistem como uma necessidade estética entre aqueles que escutam e transmitem.

\section{THE DIGITAL URBAN NARRATOR IN FOCUS: THE CASE OF MARCO ALMEIDA, THE "MARAGATO"}

ABSTRACT: This article intends, from the concepts of literary and media studies, to prove the existence of one oral urban-digital narrator. Our reflection will be organized in 4 periods: 1) Locating the field: The Restinga neighborhood, in which we will unveil, besides this peripheral area and its narrators, our motivations towards this research; 2) The relationship among the academic world, periphery and narrative: the remediation and the digital, focusing on elements of digital studies and the remediation concept, to present oral urban-digital narrative and our relationship as researchers with the inhabitants of this peripheral neighborhood; 3) The concept of digital hiperficcional storytelling, about which we will be attempting to discuss, in order to, therefore, conceptualize the urban-digital narrator, from the interactive-fictional narrative of "Maragato" and; 4) Finally, we will report some of the conclusions we reached with our research.

KEYWORDS: Media studies. Oral urban-digital narrator. Narrative. Periphery.

\section{REFERÊNCIAS}

\section{Livros:}

AARSETH, Espen J. Cybertext. Perspectives on Ergodic Literature. Baltimore; London: The Johns Hopkins University Press, 1997.

BAUDRILLARD, J. Simulacros e Simulações. Lisboa: Relógio D’Água, 1991.

BOLTER, Jay David. Writing Space. Computers, Hypertext and the Remediation of the Print. New York: Routledge, 2011.

CARDOSO, Gustavo. Os Media na Sociedade em Rede. Prefácio de Manuel Castells. Lisboa: Fundação Calouste Gulbenkian, 2006.

CARDOSO, Gustavo; COSTA, António Firmino da, et al. (Orgs.). A sociedade em rede em Portugal. Porto: Campo das Letras, 2005.

CASTELLS, Manuel. A Galáxia Internet. Reflexões sobre Internet, Negócios e Sociedade. Lisboa: Fundação Calouste Gulbenkian, 2007.

CORRÊA, Elizabeth Saad. Da remediação à premediação: ou de como a sensação de imediatismo da sociedade digital dos anos 1990 evoluiu para um clima de contínua antecipação do futuro no século XXI. RichARd GRuSin, São Paulo, ano 7, n. 2, jul./dez. 2013, p. 163-172. 
COULDRY, Nick. Media, Society, World. Social Theory and Digital Media Practice. Duke University Press, 2008.

GONÇALVES, Diana. Entrevista a Richard Gruisin. Comunicação e Cultura, n. 10, 2010, p.157-169.

GRUISIN, Richard; BOLTER, Jay David. Remediation. Understanding New Media. Cambrigde; London: First MIT Press Paperback Edition, 2000.

LEÃO, Lucia. O Labirinto da Hipermídia. Arquitetura e navegação no ciberespaço. São Paulo: lluminuras, 2005.

MARTINS, Beatriz Cintra. Autoria em rede - um estudo dos processos autorais interativos de escrita nas redes de comunicação. São Paulo: B. C Martins, 2012.

McLUHAN, Marshall. Understanding Media. The extensions of man. Routledge and Kegan Paul, 2001.

PORTELA, Manuel (Coord.). Literatura no Século XXI. Revista de Estudos Literários,, Coimbra, n. 2, 2012.

RYAN, Marie-Laure. Narrative as Virtual Reality. Imersion and Interactivity. In: Literature and Electronic Media. Baltimore; London: The Johns Hopkins University Press, 2001.

SANTAELLA, Lucia. Linguagens líquidas na era da mobilidade. São Paulo: Paulus, 2007.

Matrizes e Linguagens do Pensamento. Sonora Visual Verbal. Aplicações na Hipermídia. São Paulo: lluminuras; FAPESP, 2005.

. Navegar no Ciberespaço. O perfil cognitivo do leitor imersivo. São Paulo: Paulus, 2004.

Sites:

A Vida Reinventada - Pressupostos teóricos para análise e criação de acervo de narrativas orais. Disponível em: <http://www.ufrgs.br/vidareinventada/site>. Acesso em: 15 mar. 2013.

CEIA, Carlos. E-dicionário de termos literários. Disponível em:

$<$ http://www.edtl.com.pt/index.php?option=com_mtree\&task=viewlink\&link_id=68\& Itemid=2>. Acesso em: 8 fev. 2014. [Publicação on-line]

CORRÊA, Regina. Literatura. Texto. Hipertexto. Terra roxa e outras terras. Revista de Estudos Literários, Londrina, v. 8, 2006, p. 30-43. Disponível em: $<$ http://www.uel.br/pos/letras/terraroxa/g_pdf/vol8/8_4.pdf>. Acesso em: $17 \mathrm{dez}$. 2012. 
HAGUENAUER, Cristina; CARMELA, Regina. Narrativas Digitais, Narrativas Cinematográficas e o Olhar do Contador de Histórias. Hipertexto. Rio de Janeiro, v. 2 , n. 1, jan-jun 2012. Disponível em:

$<$ http://www.latec.ufrj.br/revistas/index.php?journal=hipertexto\&page=article\&op=vi ew\&path[]=324\&path[]=442>.

Hiperficção: My Body by Shelley Jackson. Disponível em: $<$ http://diglitmedia.blogspot.com.br/2007/05/hiperfico-my-body-shelleyjackson.html>. Acesso em: 6 mar. 2013.

Joyce, Michael. Afternoon, a story. Disponível em: <http://www.wwnorton.com/college/english/pmaf/hypertext/aft/index.html>. Acesso em: 14 mar. 2013.

PORTELA, Manuel. O Hipertexto como Metalivro. Disponível em: <http://www1.ci.uc.pt/pessoal/mportela/arslonga/MPENSAIOS/hipertexto_como_m etalivro.htm\#L3>. Acesso em: 20 mar. 2013.

Programa Ponto G - Marco Maragato. Disponível em: <http://www.programapontog.blogspot.com.br/>. Acesso em: 27 fev. 2013.

Rádio Comunitária. Disponível em: <http://www.rdcwebbrasil.com/locutor.php?id=10>. Acesso em: 10 mar. 2013.

Revista Ciberlegenda, n. 3, 2000. Disponível em: <http://www.uff.br/mestcii/denis5.htm>. Acesso em: 6 mar. 2013.

RYAN, Marie-Laure. On Defining Narrative Media. Disponível em: <http://www.imageandnarrative.be/inarchive/mediumtheory/marielaureryan.htm>. Acesso em> 18 mar. 2013.

SOUZA, Marcelo. Narrativa Hipertextual Multimídia: um modelo de análise. Disponível em: <http://narrativahipertextualmultimidia.files.wordpress.com/2011/03/narrativa_hiper textual_multimc3addia.pdf $>$.

Texto recebido em: 06/06/2014. Texto aprovado em: 14/07/2014. 